\title{
Boys' Clubs
}

\section{William Byron Forbush}

To cite this article: William Byron Forbush (1909) Boys' Clubs, The Pedagogical Seminary, 16:3, 337-343, DOI: $10.1080 / 08919402.1909 .10532588$

To link to this article: http://dx.doi.org/10.1080/08919402.1909.10532588

曲 Published online: 30 Aug 2012.

Submit your article to this journal $\pi$

III Article views: 3

Q View related articles $\sqsubset$ 


\section{BOYS' CLUBS ${ }^{2}$}

\section{By Wrimiam Byron Forbuse}

Boys' clubs express more directly, generally, and permanently than any other agency, even than the home or the school, the two central interests of boyhood: play and friendship. They are therefore of the greatest importance both as objects of study and as means of education. Their relation to play is obvious, but is emphasized by the remark that seventy-eight per cent. of all spontaneously formed boys' organizations are for the purpose of outdoor physical activities and that the percentage of those in which the play element is not central is negligible. Their relation to boys' friendships is equally obvious, but is also emphasized by the observation that in our day, when residence in cities is becoming the rule, boys are over-socialized before their time and are consequently more thoroughly influenced by the companionships they form than they ever were before. The universality of boys' clubs as the expression of play and friendship is indicated by a study made at Clark University, which seems to prove that eighty per cent. of all boys at one time or another belong to some childish society, a percentage practically equal to all those who ever had a chance thus to organize.

So much for boys' clubs organized by boys. Of clubs organized by adults for boys similar statements may be made; for they too, if they be successful, appeal to the same two instincts, of friendship and of play.

Instructive as is the study of the boys' spontaneous club"the gang," as it is often called-we must confine our remarks this afternoon to the club formed by adults for the benefit of boys.

Boys' clubs have been considered to be of two types: those which gather boys en masse and those which gather them in small groups. Of the former are the big clubs for newsboys and street urchins. Of the latter, are smaller clubs in social settlements and churches. Naturally-because philanthropy was zealous before it was carefn1 - the mass clubs came first, beginning about forty years ago. But the distinction of type is vanishing, for to-day a club is a mass club usually because

1 An Address before the Conference on Child Welfare at Clark University, Worcester, July, rgog. 
it has not succeeded in getting enough workers to divide the mass into groups, and a group club usually endeavors by a federation of groups to attain some of the ésprit de corps of the mass.

A more instructive approach to the subject will be to consider what some of the activities of these boys' clubs are. The most successful activities, as the writer has already stated, are those based on play and friendship. This statement seems to have no exception.

Boys' clubs are often said to be a kind of school. Many of their activities are distinctly and graciously educational, and formal education is learning much from the informal methods of education used in the boys' club; but the boys' club that began to become a school before it had encouraged play among its boys or friendship with its boys would soon lose its boys altogether.

And so of religious boys' clubs. It is not to be denied that boys' clubs tuay rightly be used for religious ends, but many a church organization for the young bas gone fallow or become a girls' society because it was too stiff to play or too formal to find room for fellowship.

On the other hand, most adult workers with boys have found it both necessary and wise in the use of play and friendship to seek a level of expression for those instincts as high at least as the least common denominator of the gang. I know a reputable business man who has, for a number of years, found pleasure in giving freely to a group of boys his companionship in automobile riding, theatre-going and card-playing, and yet a number of boys are continually forsaking him for no other reason, I believe, than that they have outgrown him.

One of the most wholesome methods of utilizing play and friendship in boys' clubs is seen in the service of men who have engaged with boys in nature study, field work, woodcraft, scouting and camping out. The nature study work of Dr. Hodge, Dr. Bigelow and Mr. George E. Johnson, the farm and garden work of Mr. O. J. Kern, Mr. Rufus Stanley and the Cornell University people, the revival of the better part of Indian life by Mr. Thompson Seton, the scouting parties which General Baden-Powell has scattered through England, and the excellent camps, conducted both by Y. M. C. A. secretaries and by schoolmasters, are familiar instances which illustrate and, I think, do not strain too much the term, boys' clubs.

Some workers have, more or less consciously, endeavored to utilize other well known instincts of boyhood beside play and friendship. The Boys' Brigades recognize the love of combat and of rhythmic action. There are varions self-governing 
clubs, which appeal to the dawning sense of law and order and, especially among Jewish boys, the desire to conduct argumentative debates. A fraternity called the Knights of King Arthur, resting upon that whole range of chivalric instincts, which has caused psychologists to characterize adolescence as a medieval period, has actually revived and is reproducing in hundreds of instances knightly castles, tournaments and quests.

Clubs that meet in the winter time seem to tend to crystallize into more formality than those that can get outdoors, and so, in church, Y. M. C. A. and settlement, one may expect to find everywhere : atbletic clubs, represented chiefly by basket ball ; clubs of manual work, busy usually with raffia, woodwork, cobbling and printing; and clubs whose intellectual labors are dramatics and debating.

The extent of boys' club work in this country is hardly recognized by those who have not made it a special study. The writer has catalogued nearly iso large clubs for street boys which may be supposed to be reaching 100,000 members annually. The Y. M. C. A. probably reaches twice as many. Two hundred social settlements must be reaching at least a hundred boys apiece. It is calculated that the churches are offering young people's societies or boys' clubs to at least one out of five of their Sunday School boys, and thus are reaching at least half a million. I have a list of as many as twentyfive nationally organized movements for the uplift of boys which have officers, literature and large memberships. Not all this work is well done and the total of it is not enough, but it is all worth doing.

Going a little deeper than methods, we may approach the principles that underlie boys' clubs by asking as to the results from boys' clubs in two interesting fields : education and character-making.

Aside from what the boys' club bas taught the school as to the value of play work and hand work, the boys' club has in itself at least two important relations to the educational system of the country. One, which comes through the recognition of play. is the opportunity which appears in the club to allure the illiterate boy or the boy who has left school back to the school. Many a lad by the loosening up of his muscles or the awakening of his manual powers in the play work of the club has been won back to the manual or technical courses of the schools. So important a link between the boy and the school, bas this been recognized to be, that boys' clubs have been formed, with this very purpose in mind, in the evening educational centres of Boston and in some libraries and playgrounds. 
Another relation of the club to the school appears, in the exercise of personal friendship in the club, in the direction of boys towards their vocations. No important choice in America is attended by so little deliberation or so many accidents as the choice of a calling, unless it be the choice of a wife. While Professor Frank Parsons was the first formally to institute Vocational Bureaus, every wise boys' club leader and Y. M. C. A. secretary has, for years, recoguized the task of vocational advice as the most important function of his daily work, and in the fulfilling of this function has made the republic deeply his debtor.

In studying the character-making work of boys' clubs we come to one of the most complex considerations as well as the most important one in boys' club work. It may be fairly said that few, if any, adults associate with a group of boys for any length of time without having as their distinct purpose either their uplift or their seduction. The mere joy of such association without some ulterior end usually palls upon the adult mind. Probably, also, nobody ever does boys quite as much harm or good as he intends to. The young character, like the young intellect, has a way of developing itself regardless of well meant interferences from the laying on of adult hands. Yet who would doubt that a central and often a deciding influence in a boy's life comes through the directed play and the carefully guarded friendships of a boy's club?

Among the character-forming influences of a club our best. judgment ranks as easily first the influence of the adult leader upon the boys and the influence of the boys upon each other.

Theoretically, a man might hope to influence a boy more directly and potently individually than through the machinery of a club. A few men, of strong magnetism and sympathy, can do this. Most of us, however, find that we have lost the dialect, if not the language, of childhood and that we need the club both in order that we may learn to understand the boy and that be may learn to understand us. I recall my own experiences in camping out with various groups of boys as a proof of this. I was educated, as many boys are, to the intent that I might become a perfect lady, and when I became a man my desire to be of service to boys was pathetically thwarted by my inability to have real points of contact with them. The outdoor bardship and play have furnished that contact. I returned last Tuesday from camping out for ten days with twenty-two boys, who six weeks ago were listening to an address from me with wild respect, but as a perfect stranger. Since then we have swam together and played ball together and together built our camp fre, and I have cooked for them and bound up their wounds. To-day they have begun 
to know me and to like me, and they have even given me a nickname, thus admitting me into their tribe. To-day I know them, some of them nearly as well as their own parents do. Some day may I not hope, when passion changes to control and docilities to destinies, to coin these fellowships into character?

So firmly convinced are advanced religious educators becoming of the essential importance of the enlightened influence of the adult companion upon boys in character-building that they are insisting that real teaching in Sunday school cannot be done without it. The matter of verbal ethical teaching has always been felt to have its perils : there is question whether it be not actually pernicious without real communion of spirit. To the stranger who would fain, even with noble motive, trespass upon his shrine and burglarize his soul, the child may be imagined to respond, in a paraphrase of an Old Testament sentence, "Take thy shoes from off $m y$ feet, for the place whereon thou standest is holy ground.'

It may be queried whether the influence of boys upon each other is not more potent as well as more direct than that which any adult can possibly exert. This is probably so because of a fact of soul life which even psychology has so far neglected, the fact that the adolescent is not yet fully an individual but is still, to some extent, integrally a portion of the group. Just as certain low orders of animal life resident in a mass have some physical functions which they perform as a group and others which they perform as individuals, so by analogy, boys seem to act en masse as well as alone, even on the highest planes of their being. There may be different explanations of this. When I saw fifty boys studying their Bibles together outdoors one fine weekday morning at a Y. M. C. A. camp, I thought it was imitation. When I heard of the ludicrous response to an evangelist's appeal by which a group of boys, in answer to his request that if they wanted to be saved they meet in a certain corner of the room, all proceeded to pile themselves up there, it seemed like hypnosis; The fact that when boys come forward for church membership they generally do so in groups or by classes, suggests that it is their gang instinct that calls them and that they interpret the church, as Professor Coe phrases it, as "God's gang."

The fact which I have adverted to, to which Dr. Joseph S. Waiton first called my attention, that boys to-day in city conditions are oversocialized before they are fully individualized, a fact borne out by the observation that country boys are less strongly infuenced on moral levels by the gang, suggests that the group influence is partly artificial as well as natural and is to a degree unwholesome. 
Whatever the explanation, the group action of boys in moral matters is a fact of such universal observation as to become of extreme importance and to suggest that perhaps no boy can be measured as to the limits of his moral possibilities while he is a boy until each impulse and action is related by inference to the impulses and acts of his crowd. The advantage of the artificially formed group with its adult leader over the street gang in moral result seems to be that it is possible to key the group ethics up to the level of the best boy, whereas in the gang it is apt to sink into, or beluw, the level of the worst. The aduit usually finds that every group has its one or two keyboys, and he manipulates the group through them. This, which is a commonplace in school teaching, is more than a mere device in boys' clubs. Even more effective, though not so noticeable, in results is the constant, silent attrition of all the boys, leaders and those led, on each other. Both the power and the limitations of self-government schemes, in farm schools or boys' clubs, appear just here. Boys can by such devices rise to the highest level that is existent in the group, but can they, unaided, rise any higher than their own level?

Out of this interplay of influences the adult leader can gradually come to discern this one fact, that he is a more or less passive witness of the formation of a boyish community whose commencement is sound and whose influences are in the main a wholesome school for life

This work is evidently not one for a mere holiday or for good-natured social volunteering. The issues are too serious, the evolutions are too gradual and slow.

The more one is experienced in work with boys the more he is impressed with a few facts of boy life, which are in the main encouraging but which intensify the earnestness of the problem.

One impression is of the general wholesomeness of boy nature. The testimony, from juvenile court judges, reformatory heads, schoolmasters and workers in religious circles is strongly unanimous that a boy, minus his environment and plus all the heredity in the world, is a pretty good sort. The number of degenerates, theological or actual, is negligible. The degree to which you have the boy on your side when you try to do him good is extraordinary. The fact which was discovered by accident, for example, that in a boys' camp, where there had apparently been no opportunity to do so, every boy had said his prayers, is a case in point.

On the other hand the unpleasant sophistication of modern boys, and especially of city boys, is a modifying fact of great moment. It takes a week in tents to break the crust off a boy, and I fancy the average Sunday school teacher never lifts a corner of it. 
But again this sophistication usually rests side by side with an appalling ignorance. The boy isold beyond his time in things which he has seen but he is still a child in experience. Ignorance upon sexual matters is an example which some writers and workers have lately called attention to, an ignorance which no mere formal instruction can apparently cure but which an enlightened development of mind and body can cope with.

I have, however, personally been impressed more by the ignorance of the import of life itself, as manifested in absence of purpose, unwillingness to get ready, lack of sense of the value of money and unwillingness to wait for the rewards of industry. 'This type of boy is too often coddled in the boys' club. Sometimes the best thing, next to patience, that the leader can give him is his disapproval.

'To the boys' club worker, unknown and unappreciated, who meets his boys only once a week in winter and for a bare fortnight in summer, his work may often seem trivial and unproductive. Those who watch it often do so with half contempt and amusement. But it is not so. To the club the boy brings that torch of life which sometimes school and home fail to light-enthusiasm. Here he exercises that instinct which alone keeps men alive and young and at work-play. Here he uses a power so precions that it is given only to youth-the power of making friendships. And here he finds what Charles Kingsley dying said was life's secret-"a friend."

The club is, therefore, a special school, educating the boy in freer fashion than at the desk of the schoolhouse, capturing his presuppositions, allying itself with his enthusiasms and often helping to determine his life's vocation. The club is also an essential agency in religious education, mitigating the fervor and unreality of direct ethical teaching by allowing room for real fellowship between teacher and scholar and giving a chance, in the best clubs, for some of that actual practice in morals which is necessary to any mastery of them. It is, in our time, the needed supplement to the home, affording to boys that larger social education which its own limited numbers cannot give and offering to club leaders so much of the parental function that it may be said to revive in a truer and holier sense the old ecclesiastical office of the godfather, or sponsor for the social and moral future of the child. 